\title{
Embracing Product Innovativeness in Technology Firms: The Impact of Management Model Principles
}

\author{
Pınar Büyükbalcı, Esin Ertemsir, Zayneb Boukari
}

\author{
I The most resilient companies foster a pervasive culture of innovation at all levels of \\ the organization - one that values risk-taking, embraces experimentation, and \\ considers failure an inevitable part of thinking boldly. ” \\ Lynne Doughtie \\ Former Chairman and CEO of KPMG
}

\begin{abstract}
Extending the debate on how to enable and manage innovation requires a discussion of the potential beneficial impact of management models and corresponding principles. In this paper, we draw on literature involving product innovativeness and management models to propose that product innovativeness is facilitated and influenced by practices and principles traceable in different management models. We test our hypotheses with data from a sample of high technology firms. Findings suggest that management models and principles have varying impacts on product innovativeness. Specifically, we found the principles of obliquity, emergence, and intrinsic motivation as significant enablers of product innovativeness, along with extrinsic motivation. Also, each management model differently impacted and fostered product innovativeness.
\end{abstract}

\section{Introduction}

A company's management model reflects its managers' choices, decisions, systems, procedures, people, and organizational structure (D'Amato, 2015). Companies nowadays are often faced with transforming their management models to cope with discontinuous change in the current hyper-competitive business landscape. Under turbulent conditions, organizations develop skills, structures, and principles that enable them to build an innovative organizational climate and thus achieve competitiveness (Cooper \& Kleinschmidt, 2000).

Our focus in this paper is to reveal the impact of management models on product innovativeness. We will do this by trying to discover how specific principles in a company's management model affect product innovativeness. The study targets technology-oriented firms strongly relying upon innovativeness to stay competitive.

As far as we know, although certain principles in company management models have been central to recent discussion in literature, their impact on innovativeness has not been empirically studied from a management model perspective. This study offers a discussion of management models and their principles that addresses this gap, and attempts to extend the relevant theoretical debate by examining impact on product innovativeness. From a practical perspective, we suggest a guideline for tech-oriented companies to raise their awareness by highlighting various principles that foster product innovativeness.

\section{Summary of Literature Insights}

\section{Definition of Management Model}

Examining the history of management models in the last century and a half, Bodrozic and Adler (2018) highlighted that, "the concept of management model has not received much scholarly attention and terminology has been loose". They define a "management model" as "a distinct body of ideas that offers organizational managers precepts for how best to fulfill their technical and social tasks".

A management model is a managerial tool that focuses on the operational tasks of organizational procedures and acts as a guideline that unifies fundamental 


\section{Embracing Product Innovativeness in Technology Firms: The Impact of Management Model Principles}

\section{Pınar Büyükbalcı, Esin Ertemsir \& Zayneb Boukari}

elements of a company: the practices, processes, and principles (Basile \& Foraci, 2015). According to this definition, in this paper we attempt to discover the relationship between the practices \& processes of product innovation, together with management model principles.

Despite being strongly related to each other, management models and business models are distinct concepts (Birkinshaw \& Ansari, 2015). "Business models" reflect the ways a company earns money (Osterwalder, 2004) by describing the business process as a system of interdependent activities (Zott \& Amit, 2010), which in the end leads to value creation. Although the nature and implications of these interdependent activities might differ across industries (Herting \& Schmidt, 2020), in general, a business model specifically refers to a target customer or customers, key activities, key resources, partners, and other features, which altogether make up the value creation activities of a firm. On the other hand, "management models" are the framework that reflects upon the dominant "managerial logic of an organization" (Prahalad \& Bettis, 1986), or simply, "the basic choices (a firm makes) about how work gets done" (Birkinshaw, 2010). In this regard, a management model describes "how activities are coordinated, how decisions are made, how objectives are set, and how employees are motivated" (Birkinshaw, 2012).

In this study, our conceptualization of a "management model" is based on the principles and framework of
Birkinshaw (2012), described as, "the choices made by executives of a firm regarding how they define objectives, motivates effort, coordinate activities, and allocate resources- in other words, the definition of how work of management gets done". As underlined here, the management model of a firm focuses on making choices regarding four main pillars: defining objectives, motivating efforts, coordinating activities, and allocating resources (Birkinshaw \& Goddard, 2009; Birkinshaw, 2012). Under each pillar, there are both traditional and alternative principles that represent aspects of the model's structure, as depicted in Figure 1. Traditional principles are those that firms have implicitly used for generations, while alternative principles are either "just beginning to be adopted", or which have not yet been widely used (Birkinshaw, 2012; Birkinshaw \& Ansari, 2015).

In the Figure 1 model, "coordinating activities" (labeled as "managing across") are described on a continuum, with "bureaucracy" and "emergence" on two sides (Birkinshaw, 2012). Bureaucracy serves as a means of coordination through formal rules and procedures to ensure standardized behavior that will in turn lead to output consistency. As an alternative principle, emergence focuses on a spontaneous order where employees coordinate activities themselves, yet according to minimal pre-defined guiding structure.

The next dimension, "decision making", focus on how to allocate resources. These are traditionally managed through a principle of "hierarchy", a notion that

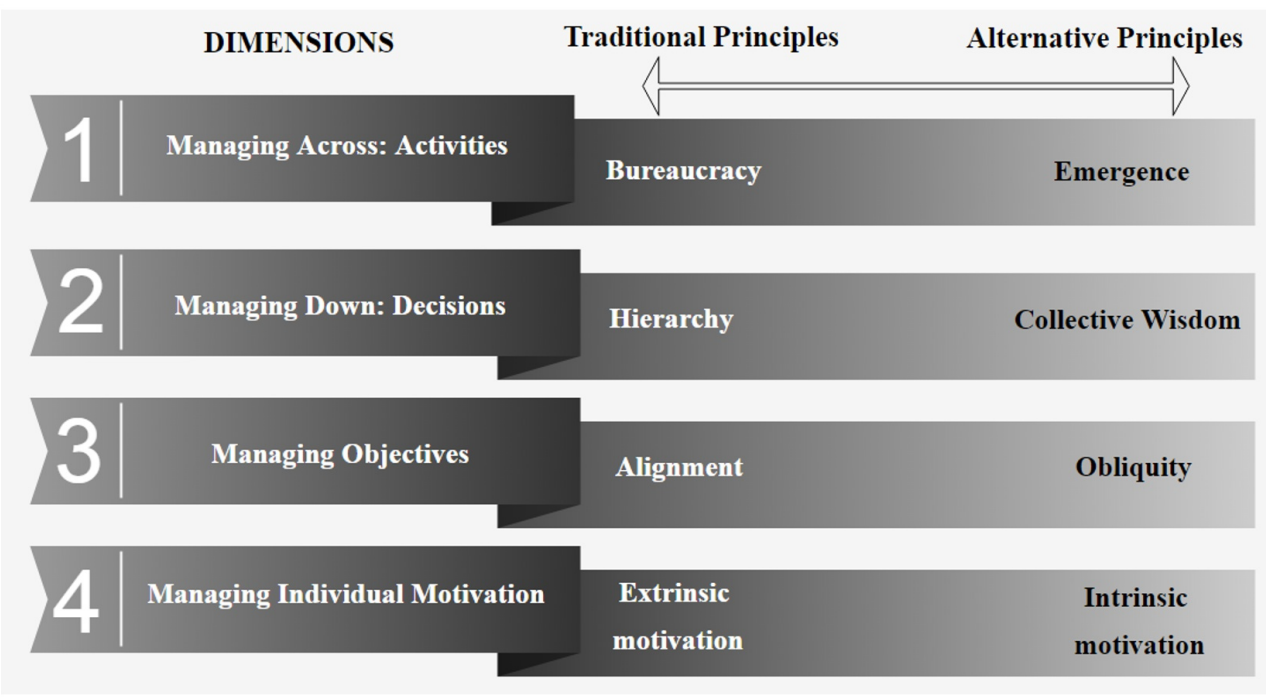

Figure 1. The four dimensions of a management model (adapted from Birkinshaw, 2012) 


\section{Embracing Product Innovativeness in Technology Firms: The Impact of Management Model Principles}

\section{Pınar Büyükbalcı, Esin Ertemsir \& Zayneb Boukari}

managers have the legitimate workplace authority over their subordinates (Foss \& Saebi, 2015). The alternative principle, "collective wisdom", suggests that under certain conditions the aggregated expertise of a large number of people can produce more accurate forecasts and better decisions than those of a small number of experts (Birkinshaw, 2012).

"Objective setting" is another critical dimension for a management model. In business contexts, the traditional principle of "alignment" means that all employees are working towards the same common objective in an aligned, step by step manner, while the "oblique" principle on the alternative side suggests that goals are best achieved when pursued indirectly. In other words, under "obliquity", a higher order general goal gets stated, while each unit is expected to design their own specific business objective to reach that higher order, generally defined goal (Birkinshaw, 2012).

The final dimension is "motivating employees", which can happen "intrinsically" or "extrinsically". If they are motivated intrinsically, which represents the alternative approach in this model, then the source of motivation is the inner interest or the satisfaction employees feel while doing their job. If they are motivated extrinsically, mostly observed in the traditional approach, then the source of motivation is often material rewards and external incentives (Casebourne, 2014).
Based on different combinations of management principles, four major types of management models have been put forth by Birkinshaw (2012) (see Figure 2).

As depicted in Figure 2, the "Discovery Model" bases on alternatives principles and is mostly adopted by small and medium sized ventures, or by designated units within special projects by large, established companies operating in an ambiguous, uncertain, and fast changing business environment. The "Planning Model" instead fully adopts traditional principles and when applied can be widely beneficial in mature industries where jobs are performed in a linear manner, and where there is a high degree of market predictability. The "Quest Model" and "Science Model" fall in between and employ various combinations of both alternative and traditional principles. In the "Quest Model", with a combination of collective wisdom and emergence as alternative principles, along with traditional extrinsic motivation and alignment, employees get told what to do, not how to do it. This model helps established and growing companies that operate in a competitive arena and thus need to try to differentiate themselves. The "Science Model" adopts the alternative principles of intrinsic motivation and obliquity, combined with traditional hierarchy and bureaucracy. This model is mostly practiced in special engineering project firms and other $\mathrm{R} \& \mathrm{D}$-based business strategies. It suggests tight means and loose ends with formal rules and structures, as well

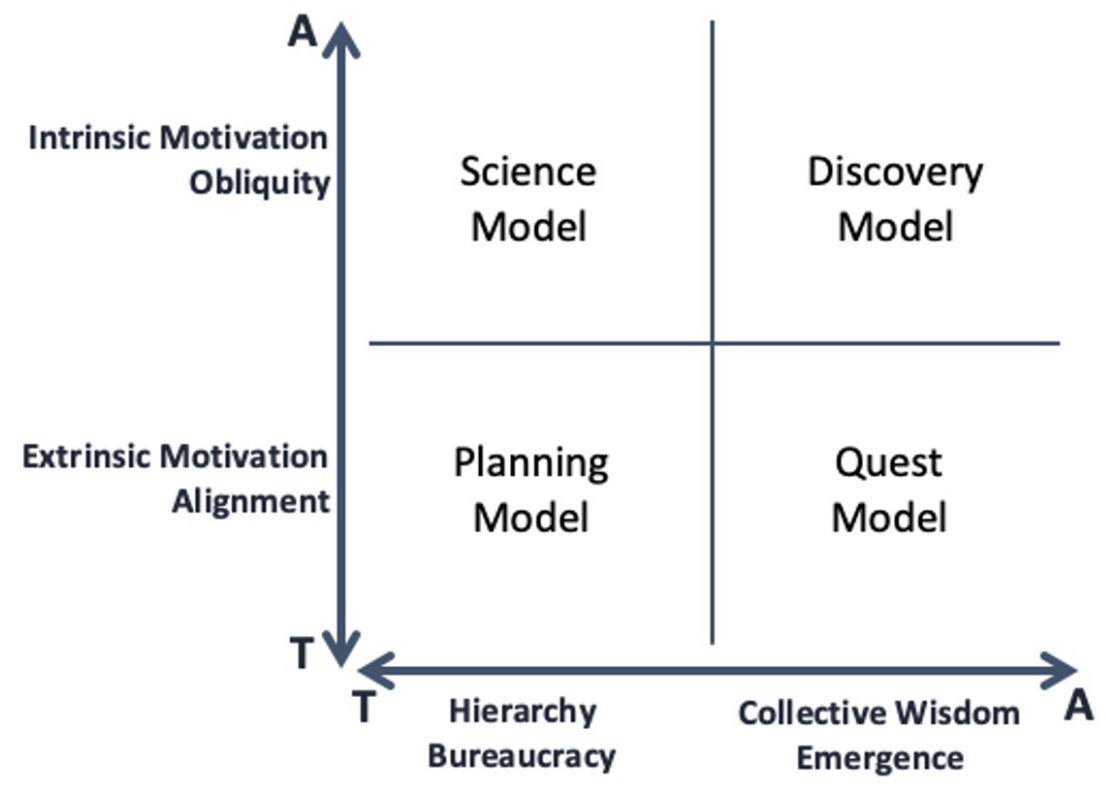

Figure 2. A framework on types of management models (Birkinshaw, 2012)

(“T": Traditional management model principles / "A": Alternative management model principles) 


\title{
Embracing Product Innovativeness in Technology Firms: The Impact of Management Model Principles
}

\author{
Pınar Büyükbalcı, Esin Ertemsir \& Zayneb Boukari
}

as authority in decision making based on scientific expertise, accompanied by intrinsic motivation to conduct science and sometimes necessary obliquity in achieving goals.

\section{Product Innovativeness}

Several definitions of "innovativeness" are available in related literature. Among them, a widely used one treats innovativeness as a company's propensity to introduce and support new ideas, novelty, experimentation, and creative processes that may result in new products, services, or technology (Yusof, 2010). From a rather broad perspective, innovativeness has also been defined as a firm's capacity to engage in innovation; that is, introducing new processes, products, or ideas in an organization (Hult et al., 2004).

Product innovation involves understanding customer expectations, providing user convenience, and capture market demand. Damanpour (1991) defined "product innovation" as "new products or services introduced to meet an external and market need", while Conway and Steward (2009) described it as "a novel tangible artefact, including materials and components, those based on high as well as low technology, and those aimed at individuals or organizations". This study adopts Wang and Ahmed's (2004) framework of conceptualizing product innovativeness as, "the novelty and meaningfulness of new products introduced to the market in a timely fashion".

The impact of product innovation on a tech-oriented company's success is assumed to be related to the degree of novelty. In other words, a product new to a company but not to the market can be regarded as a minor innovation, some would even qualify it as an imitation, whereas a product new to the market represents a more drastic innovation (Mohnen \& Hall, 2013).

Innovation types and firm innovativeness are both influenced by the interaction among resources, organizational structure, coordination, and motivational practices, which make a company's management model a critical factor either enabling or disabling innovation. Especially in tech-based enterprises, product innovation emerges as a proxy for agility and competitiveness, which prepares the ground to clearly differentiate the firm from its rivals and thus provide further growth and market expansion. The management model should also be well defined and flexible enough to anticipate and respond to abrupt changes in the business landscape, and thereby support innovative processes.

\section{Methodology}

This paper comes out of a research project that has been investigating the relationship between management models, principles, and innovativeness dimensions. The research's key steps were as follows: First, we identified the main research objective after a literature review conducted to better understand the gaps as well as unveil the main constructs and related variables. Following this, we discussed possible relations between variables and thus developed hypotheses. In the next step, we designed a questionnaire as the main measurement tool and decided the sample. After we collected data from the sample, we ran analyses and tested hypotheses to articulate the key findings. Further information is available below on the questionnaire, sample, and methodology.

We used a structured questionnaire for data collection. The questionnaire included 55 questions, 16 of which aimed to identify a company's type of management model, while 29 of them aimed to identify dominant dimensions in company innovativeness. The remaining 10 questions dealt with demographic indicators. Of these questions, 7 items directly aimed to measure product innovativeness. Questions measuring product innovativeness and the firm's tendency towards a specific management model pillar adopted a multipleitem six-point summated rating scale $(1=$ completely disagree, $6=$ completely agree).

To identify each management model, items were derived from the specific definitions and brief test tools proposed by Birkinshaw (2012). To measure product innovativeness, we extracted related items from Wang and Ahmed (2004). Here are some example setup questions in this section: "In new product and service introductions, our company is often first-to-market", "Our new products and services are often perceived as very novel by customers", "In comparison with our competitors, our company has introduced more innovative products and services during the past five years", and "New products and services in our company often take us up against new competitors". Finally, the demographic questions were included to get information on variables such as age, size, and field of operation of companies in the sample. 


\title{
Embracing Product Innovativeness in Technology Firms: The Impact of Management Model Principles
}

\author{
Pınar Büyükbalcı, Esin Ertemsir \& Zayneb Boukari
}

Since the study focuses on product innovativeness in technology ventures, the "science parks" at technical universities were selected as a target population, due their pioneering role in developing and commercializing technology. In our local environment, the 2 science parks in Istanbul established by technical universities host in total 723 companies. The sample in this study consists of firms operating at the science park of Yildiz Technical University, making it an acceptable and accessible population for the study. Yildiz Technical University Science Park was founded in 2003 and currently hosts 433 firms. The sample represents hightech firms that compete in highly dynamic environments and whose survival is mainly due to their innovative capabilities.

In this research, we used convenience sampling on 90 questionnaires that were collected between the end of 2016 and the beginning of 2017. However, among these 90 questionnaires, 10 were incomplete and thus 80 firms were included in the final analyses.

Tabachnick and Fidell (1989) suggested that the minimum number of subjects for each predictor or independent variable in a regression analysis should be at least 5 times more than the number of independent variables. In other words, a minimum subject-topredictor ratio as 5-to- 1 is acceptable when not possible to have the recommended ratio of 20 times more cases than independent variables (Green, 1991). This study thus met the minimum number of subjects required to conduct multiple regression analyses with 80 firms, since six independent variables required at least 30 subjects.

This study used firm-level data. To reach responses highly reflective of a company's management model, data was collected mostly from founder-managers and other persons holding managerial positions. Respondents were invited to complete an anonymous survey questionnaire that took approximately 20 minutes to complete. While collecting data, we first used a self-administered survey method, with drop-off surveys and email deployment. However, the response rate was very low. Therefore, we switched to a household drop-off survey, and the questionnaires were handed to each participating firm one by one. Within a certain period, they were each directly picked up. The voluntary character of the participation was explained verbally as well as indicated in the questionnaire.

\section{Hypotheses Development}

This paper focuses on "product innovativeness", specifically "new to the market" products, and aims to study its relation with organizational management models, with specific focus on principles in management models. Current research assumes that certain principles in each management model have different impacts on product innovativeness. This is in line with the literature that emphasizes management models as traceable among a variety of management practices (Birkinshaw, 2010) and management model principles, which are manifested in organizations through certain processes (Birkinshaw and Ansari, 2015). Based on this, we assume that management model principles are manifested in product innovation processes and practices.

Accordingly, our main research question addresses whether or not alternative management principles (emergence, collective wisdom, obliquity, and intrinsic motivation) have a different impact on a company's product innovativeness compared to the impact of traditional management principles (bureaucracy, hierarchy, alignment, and extrinsic motivation). If so, how does the impact of each principle change in terms of fostering and enabling product innovativeness, especially when taking into consideration their roles in relevant management models?

Today, managers tend to involve employees in decision making processes and decentralize planning to make them internalize goals and plan actions more easily. This is especially important for progress and improvement in organizational processes that require voluntary contribution of employees at each level. Clegg et al. (2002) put forth the view that people are more likely to make efforts to innovate when they feel trusted and empowered at work. Following this, Ellonen et al. (2008) suggested that different types of trust enhance innovativeness in organizations.

Involving multiple organizational members and stakeholders in a decision-making process pays tribute to the importance of collective wisdom, which can be traced in discovery and quest models. Like the term "collective wisdom", Lave and Wenger (1991) used the term "communities of practice (CoP)" and defined it as a connection among practitioners who share ideas and solve problems. Likewise, collective wisdom is seen as 


\section{Embracing Product Innovativeness in Technology Firms: The Impact of Management Model Principles}

\section{Pınar Büyükbalcı, Esin Ertemsir \& Zayneb Boukari}

being valuable to organizations as it fosters the creation and sharing of "social capital", although, in the case of internal sourcing of employees, limitations are imposed by internal organizational sources, which sometimes demonstrate an "in crowd" perspective.

The results of related studies show that, especially in a complex and fast changing context, like that of technology-oriented companies, both centralization and formalization lead to restrictions on creativity and innovation (Ekvall, 1999). Similarly, individual level innovation capabilities and employee learning are limited when formal plans get dictated by top executives (Daft, 1978). McKnight and Chervany (2001) reveal that the positive impact of trust-related behavior and high inclusiveness can be traced in cases of strong cooperation, information sharing, informal agreements, and decreasing controls.

Thus, we hypothesize that:

\section{H1: Alternative principles of emergence and collective wisdom have a positive relationship with product innovativeness.}

Despite of the mainstream notion noting that centralization and formalization, both prominent indicators of bureaucracy (Damanpour, 1996), hinder innovation in most cases, more research is still needed to clarify the mixed relationship between bureaucracy and innovation by further exploring the impact of certain organizational features (Dougherty \& Corse, 1995). In stable and predictable environments, some degree of centralization and formalization in decision making may enhance an organization's ability to implement innovation (Harold, 2000). In line with this view, Olson et al. (1995) found that, if efficiency is the issue, then product development processes can be associated with more bureaucratic approaches. Kessler and Chakrabati (1999) found that for radical innovation projects, assigning a project leader from higher hierarchical levels will speed up the process, while for incremental projects, lower-level project leaders might be assigned. On the other hand, Lahiri et al. (2019) put a focus on hierarchical relationships and found that there might be a strong negative impact of hierarchy on product innovation if a dispute occurs between founder-inventors and innovation teams in technology ventures.

Additionally, centralization of power correlates positively with innovation, especially in new ventures
(Koberg et al., 1996), and when the business environment is rather stable. Offering international management insights, Wong (2002) noted that product managers have to both manage and coordinate new product development activities among headquarters and subsidiaries, in parallel with their company's centralization needs. In other words, a certain level of centralization and formalization makes it easier for firms to adopt and implement product innovation, especially when a technology is quite complex, or when the firm is rather young and has yet to describe the new product development procedures in their organizational framework.

The findings of this research picture a mixed relationship between hierarchy and product innovativeness, like what we observed with bureaucracy.

We observe bureaucracy and hierarchy among management principles in both planning and science models. As previously underlined, planning models are relevant to a more stable, predictable and measurable environment based on incremental innovation, In contrast, science models foster complex product development procedures by putting the implementation phase, beyond idea development, into a well-defined framework as shaped by bureaucratic and formal rules.

Accordingly, we hypothesize that:

\section{H2: Traditional principles of bureaucracy and hierarchy have a positive relationship with product innovativeness.}

Along with the bureaucratic and formal rules, the science model also includes oblique goals and intrinsic motivation. In other words, it uses tight and standardized procedures for applying ideas with complex technological procedures, but also encourages employees to seek new ways of delivering outputs, especially through idea generation processes.

Especially in creative and science-based works, where scientific progress, critical acclaim and peer review are as important as commercial ends, setting goals by following the principle of obliquity serves to make room for creativity (Birkinshaw, 2012). Highly-qualified employees in industries with science models are mostly motivated by intrinsic rewards and prefer creativity, the freedom to innovate, and recognition, compared with 


\section{Embracing Product Innovativeness in Technology Firms: The Impact of Management Model Principles}

\section{Pınar Büyükbalcı, Esin Ertemsir \& Zayneb Boukari}

extrinsic gains such as financial instruments alone (Gumusoglu \& Ilsev, 2009; Gupta, 2009). This is also in line with McGraw's (1978) proposal that simple and straightforward tasks can be enabled by extrinsic motivation, while for creative, open-ended, and complex tasks, where focused search and attention is required, such an approach may result in adverse performance outcomes.

Thus, obliquity and intrinsic motivation, both prevalent in the science and discovery models, are expected to foster product innovativeness as they create a setting for behavioral patterns to emerge and thus enable people think "out of the box".

Therefore, we hypothesize that:

\section{H3: Alternative principles of obliquity and intrinsic motivation have a positive relationship with product innovativeness.}

As mentioned above, we traced each management principle in various management models. Thus, as the following sections show, our analyses focused on the impact of management principles by taking pre-defined groupings with other principles in relevant models (as can be observed in Figure 2). Also, Figure 3 clarifies the type of management model in which we trace the hypothesized principles.

\section{Data Analysis and Findings}

\section{Descriptive Statistics}

The questionnaire sample consists of young firms, most of which were founded after 2004. The vast majority of participating companies $(72 \%)$ operate in the software industry. The rest are distributed among telecommunication technologies $(7 \%)$, pharmaceutical (8\%), hardware manufacturing (5\%), digital mobile media (5\%), and in audio and video processing technology industries (3\%).

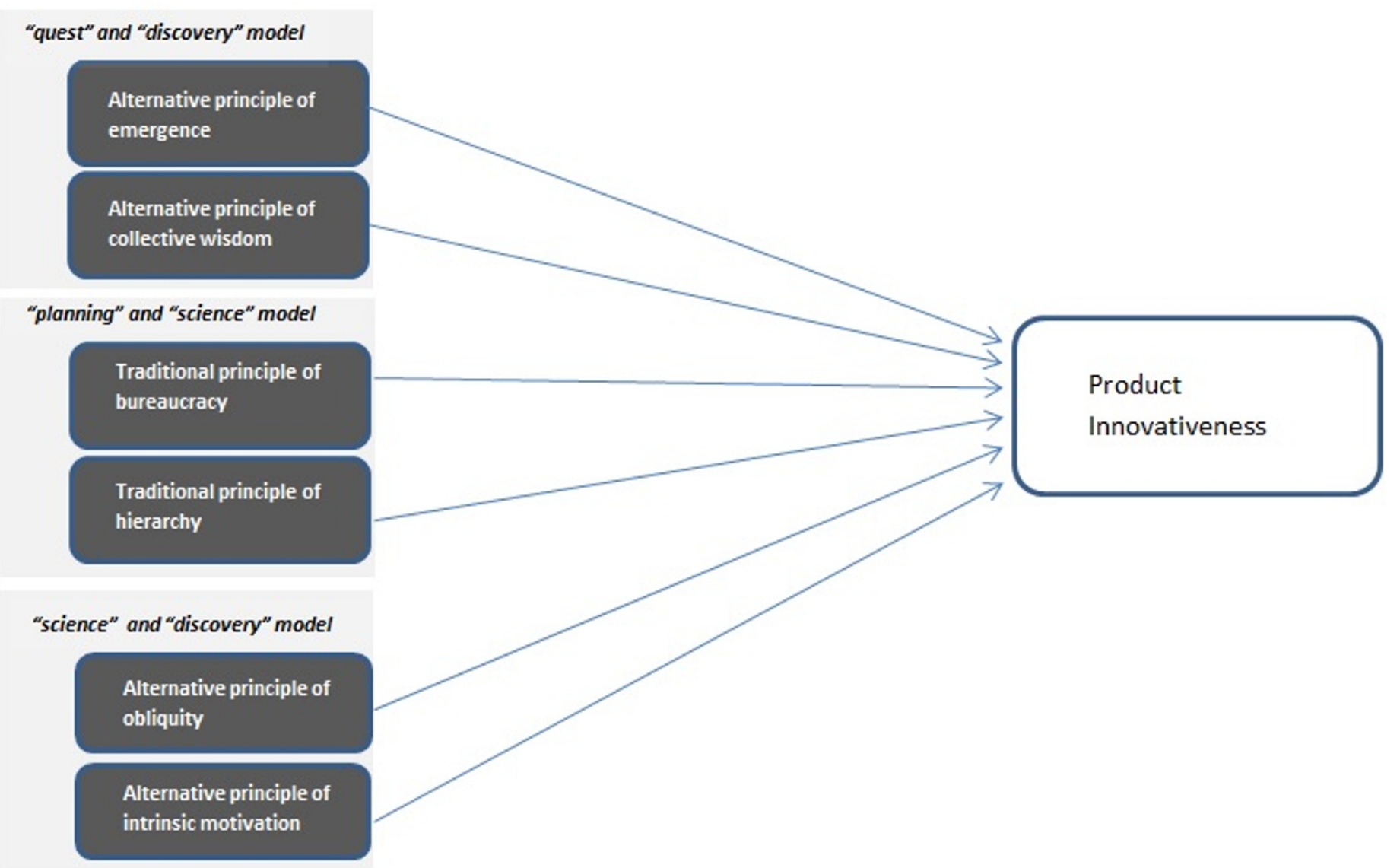

Figure 3. Theoretical Model 


\section{Embracing Product Innovativeness in Technology Firms: The Impact of Management Model Principles}

\section{Pınar Büyükbalcı, Esin Ertemsir \& Zayneb Boukari}

Respondents were either founders or individuals holding managerial positions. Specifically, $15 \%$ of the respondents were founders, with $33 \%$ high level managers (C suite staff), and the rest middle and lowlevel managers who frequently interact with higher-level managers, and thus have knowledge and experience of the company's management model.

Finally of note, $38 \%$ of the total participating companies have less than 10 employees, while $31 \%$ have between 10 and 20 employees, and the rest have more than 21 employees.

\section{Analyses}

First the relationship between management model principles and product innovativeness was calculated by Pearson's "correlation coefficient technique". The results (see Table 1), indicate a positive and significant relationship between product innovativeness and the principles of emergence, collective wisdom, obliquity, and both extrinsic and intrinsic motivation. These preliminary results provide support for the first and third hypotheses, with none revealed for the second hypothesis.

Along with the main purpose of this study, further analyses were needed to portray any underlying relationship between the variables. Thus, following correlation analysis, we further examined the impact of management models and principles on product innovativeness by linear regression analysis.

Prior to regression analysis, we tested the data set for normality, linearity, and multicollinearity assumptions, before proceeding with further multivariate analyses.

First, we calculated Mahalanobis distance values to see whether there were outliers in the data set $\left(\chi^{2}(8)=26.13\right.$; $\mathrm{p}<.001)$. No outliers were identified. Next, we created scatter plot matrices, which showed that distributions are scattered close to the elliptic shape and that linear relations exist. These results indicate that the assumptions of normality and linearity are met.

Finally, we calculated correlations between independent variables to examine multicollinearity. No strong correlations were found between variables ($0.38<\mathrm{r}<0.56)$.

Also, we acquired Cronbach's Alpha values for the product innovativeness measure (0.71) and for each group of items measuring different management models (Science Model: 0.69, Discovery Model: 0.79, Planning Model: 0.73, Quest Model: 0.67).

Table 1. The Correlations between Principles in Management Models and Organizational Innovativeness

\begin{tabular}{|c|c|c|c|c|c|c|c|c|c|c|c|c|c|c|c|c|}
\hline & Variables & Mean & $\begin{array}{c}\text { Std. } \\
\text { Deviation }\end{array}$ & V1 & V2 & V3 & V4 & V5 & V6 & V7 & V8 & V9 & V10 & V11 & V12 & V13 \\
\hline V1 & Bureaucracy & 8.34 & 2.22 & 1 & & & & & & & & & & & & \\
\hline V2 & Emergence & 6.61 & 1.73 & 0.14 & 1 & & & & & & & & & & & \\
\hline V3 & Hierarchy & 8.79 & 2.21 & $0.43^{* *}$ & 0.00 & 1 & & & & & & & & & & \\
\hline V4 & Collective wisdom & 7.70 & 2.28 & 0.04 & $0.38^{* *}$ & -0.03 & 1 & & & & & & & & & \\
\hline V5 & Alignment & 7.29 & 2.15 & 0.15 & $0.23^{*}$ & 0.13 & 0.07 & 1 & & & & & & & & \\
\hline V6 & Obliquity & 6.80 & 2.25 & 0.12 & $0.30^{* *}$ & $0.23^{*}$ & $0.28^{*}$ & $-0.38^{* *}$ & 1 & & & & & & & \\
\hline v7 & Extrinsic Motivation & 6.08 & 2.00 & 0.04 & 0.13 & 0.11 & $0.22^{*}$ & 0.14 & 0.09 & 1 & & & & & & \\
\hline v8 & Intrinsic Motivation & 7.98 & 2.07 & 0.03 & 0.16 & 0.05 & $0.36^{* *}$ & $0.22^{*}$ & 0.05 & $0.27^{*}$ & 1 & & & & & \\
\hline V9 & $\begin{array}{l}\text { Behavioral } \\
\text { innovativeness }\end{array}$ & 18.23 & 3.03 & 0.13 & $0.23^{*}$ & 0.17 & $0.36^{* *}$ & 0.19 & 0.06 & 0.12 & $0.40^{* *}$ & 1 & & & & \\
\hline V10 & Product innovativeness & 14.74 & 2.68 & 0.15 & $0.31^{* *}$ & 0.18 & $0.28^{*}$ & 0.02 & $0.51^{* *}$ & $0.28^{*}$ & $0.30^{* *}$ & $0.27^{*}$ & 1 & & & \\
\hline V11 & Process innovativeness & 17.76 & 3.00 & $0.33^{* *}$ & 0.11 & $0.31^{* *}$ & $0.24^{*}$ & -0.02 & $0.40^{* *}$ & 0.20 & $0.23^{*}$ & $0.56^{* *}$ & $0.45^{* *}$ & 1 & & \\
\hline V12 & Market innovativeness & 14.44 & 2.91 & $0.23^{*}$ & 0.10 & 0.21 & 0.10 & 0.05 & 0.14 & $0.26^{*}$ & 0.21 & $0.28^{*}$ & $0.26^{*}$ & $0.41^{* *}$ & 1 & \\
\hline V13 & Strategic innovativeness & 13.06 & 2.52 & 0.01 & 0.16 & 0.01 & $0.25^{*}$ & 0.03 & 0.05 & $0.32^{* *}$ & 0.13 & 0.07 & 0.12 & 0.09 & $0.37^{* *}$ & 1 \\
\hline
\end{tabular}

$\mathrm{N}=80,{ }^{* *} p<0.01,{ }^{*} p<0.05$ 


\section{Embracing Product Innovativeness in Technology Firms: The Impact of Management Model Principles}

\section{Pınar Büyükbalcl, Esin Ertemsir \& Zayneb Boukari}

Table 2. Impact of the Quest Model on Product Innovativeness

\begin{tabular}{|c|c|c|c|c|c|}
\hline \multirow[t]{2}{*}{ Model } & \multicolumn{2}{|c|}{$\begin{array}{l}\text { Unstandardized } \\
\text { Coefficients }\end{array}$} & \multirow{2}{*}{$\begin{array}{c}\text { Standardized } \\
\text { Coefficients } \\
\text { Beta } \\
\end{array}$} & \multirow[t]{2}{*}{$\mathrm{t}$} & \multirow[t]{2}{*}{ Sig. } \\
\hline & B & Std. Error & & & \\
\hline (Constant) & 9.86 & 1.55 & & 6.37 & .00 \\
\hline $\begin{array}{l}\text { Collective } \\
\text { Wisdom }\end{array}$ & .17 & .14 & .14 & 1.24 & .22 \\
\hline Emergence & .38 & .18 & .24 & 2.09 & .04 \\
\hline Extrinsic & .30 & .14 & .23 & 2.08 & .04 \\
\hline Alignment & -.10 & .14 & -.08 & -.75 & .45 \\
\hline $\mathrm{R}=0.42$ & $\mathrm{R}^{2}=0.18$ & $\mathrm{f}^{2}=0.22$ & & & \\
\hline$F_{(4-75)}=4.02$ & $p=0.01$ & & & & \\
\hline
\end{tabular}

Following tests for assumptions and reliability, we ran regression analyses. We used the method $\left(\mathrm{f}^{2}=\mathrm{R}^{2} /(1-\right.$ $\left.\mathrm{R}^{2}\right)$ ) proposed by Cohen (1988) to calculate the effect sizes in the regression analysis $\left(0.02 \leq \mathrm{f}^{2}<0.15\right.$ small effect, $0.15 \leq \mathrm{f}^{2}<0.35$ moderate effect and $0.35 \leq \mathrm{f}^{2}$ large effect).

Data in Table 2 reveals the impact of the "quest model" on product innovativeness.

When the results were examined, we saw that only "emergence" and "extrinsic motivation" turned out to be significant predictors of product innovativeness.
According to our findings, the overall impact of the quest management model on product innovativeness is significant $(p=.01)$, while the explanatory power of the model is moderate $\left(\mathrm{R}=.42, \mathrm{R}^{2}=.18, \mathrm{f}^{2}=.22\right)$. The quest management model accounts for $18 \%$ of the total variance in product innovativeness.

Data in Table 3 reveals the examined impact of the planning model on product innovativeness.

According to the results, the principles of bureaucracy, hierarchy, alignment, and extrinsic motivation show no significant combined impact on product innovativeness

Table 3. Impact of the Planning Model on Product Innovativeness

\begin{tabular}{|c|c|c|c|c|c|}
\hline \multirow[t]{2}{*}{ Model } & \multicolumn{2}{|c|}{$\begin{array}{l}\text { Unstandardized } \\
\text { Coefficients }\end{array}$} & \multirow{2}{*}{$\begin{array}{c}\text { Standardized } \\
\text { Coefficients } \\
\text { Beta } \\
\end{array}$} & \multirow[t]{2}{*}{$\mathrm{t}$} & \multirow[t]{2}{*}{ Sig. } \\
\hline & B & Std. Error & & & \\
\hline (Constant) & 10.83 & 1.72 & & 6.31 & .00 \\
\hline Bureaucracy & .12 & .15 & .10 & .81 & .42 \\
\hline Hierarchy & .14 & .15 & .11 & .93 & .36 \\
\hline Alignment & -.06 & .14 & -.05 & -.45 & .65 \\
\hline Extrinsic & .36 & .15 & .27 & 2.42 & .02 \\
\hline $\mathrm{R}=0.33$ & $R^{2}=0.11$ & $f^{2}=0.12$ & & & \\
\hline$F_{(4.75)}=2.27$ & $p=0.07$ & & & & \\
\hline
\end{tabular}




\section{Embracing Product Innovativeness in Technology Firms: The Impact of Management Model Principles}

\section{Pınar Büyükbalcı, Esin Ertemsir \& Zayneb Boukari}

$\left(\mathrm{R}=.33, \mathrm{R}^{2}=.11, \mathrm{p}>.05\right)$. In other words, the overall impact of the planning model on product innovativeness was not observed in this dataset. In terms of the impact of management principles, only extrinsic motivation significantly affected $(\mathrm{p}=.02)$ product innovativeness.

Following this, we analyzed the "science model's" impact on product innovativeness as revealed by the data in Table 4.

The combination of bureaucracy, hierarchy, obliquity, and intrinsic motivation altogether significantly and strongly affect product innovativeness $\left(\mathrm{R}=.59, \mathrm{R}^{2}=.34\right.$, $\left.\mathrm{f}^{2}=.52, \mathrm{p}<.05\right)$. When we examined the results of the significance tests of the calculated coefficients, we saw that on an individual basis obliquity and intrinsic motivation were significant predictors of product innovativeness.

Finally, we obtained the results in Table 5 regarding the impact of the "discovery model" on product innovativeness.

The results indicate that emergence, collective wisdom, obliquity and intrinsic motivation together have significant and strong impact on product innovativeness $\left(\mathrm{R}=.59, \mathrm{R}^{2}=.35, \mathrm{f}^{2}=.54, \mathrm{p}<.05\right)$, showing

Table 4. Impact of the Science Model on Product Innovativeness

\begin{tabular}{lccccc}
\hline \multicolumn{1}{c}{ Model } & \multicolumn{2}{c}{$\begin{array}{c}\text { Unstandardized } \\
\text { Coefficients }\end{array}$} & $\begin{array}{c}\text { Standardized } \\
\text { Coefficients } \\
\text { B }\end{array}$ & $\mathrm{t}$ & Sig. \\
\hline (Constant) & 7.06 & 1.57 & & 4.50 & .00 \\
Bureaucracy & .09 & .13 & .07 & .70 & .48 \\
Hierarchy & .03 & .13 & .02 & .22 & .83 \\
Obliquity & .58 & .11 & .48 & 5.04 & .00 \\
Intrinsic & .35 & .12 & .27 & 2.85 & .01 \\
\hline $\mathrm{R}=0.59$ & $\mathrm{R}^{2}=0.34$ & $\mathrm{f}^{2}=0.52$ & & & \\
$\mathrm{~F}_{(0-75)}=9.77$ & $p=0.00$ & & & & \\
\hline
\end{tabular}

the important impact of discovery model on product innovativeness. At the same time, in terms of the impact of principles, we observed obliquity and intrinsic as significant predictors of product innovativeness.

In our findings, we note that some unexpected relations were revealed, along with expected ones. Below we address these relations with respect to the three hypotheses presented above.

Hypothesis 1, which stated that principles of emergence and collective wisdom have a positive relationship with product innovativeness, was only partially supported as the impact of collective wisdom was not observed singly. Rather, the collective wisdom principle enables product innovativeness only when it interacts with other principles in the "quest model" and "discovery model". The emergence principle, on the other hand, enables product innovativeness, both individually and with significant impact through the "quest model" and "discovery model".

Hypothesis 2, which focused on the relationship of bureaucracy and hierarchy with product innovativeness, was weakly supported as none of the principles significantly affected nor enabled product innovativeness. Their impact was observed only through their role in the "science model", where the overall impact of including other principles (obliquity and intrinsic motivation, along with bureaucracy and hierarchy) turned out to be significant.

Hypothesis 3, which discussed a positive relationship of obliquity and intrinsic motivation with product innovativeness, was fully supported, These principles affect and thus enable product innovativeness both individually and also through the overall significant impact of the "science model" and "discovery model". 


\title{
Embracing Product Innovativeness in Technology Firms: The Impact of Management Model Principles
}

\author{
Pınar Büyükbalcı, Esin Ertemsir \& Zayneb Boukari
}

Table 5. Impact of the Discovery Model on Product Innovativeness

\begin{tabular}{|c|c|c|c|c|c|}
\hline \multirow[t]{2}{*}{ Model } & \multicolumn{2}{|c|}{$\begin{array}{l}\text { Unstandardized } \\
\text { Coefficients }\end{array}$} & \multirow{2}{*}{$\begin{array}{c}\text { Standardized } \\
\text { Coefficients } \\
\text { Beta } \\
\end{array}$} & \multirow[t]{2}{*}{$\mathrm{t}$} & \multirow[t]{2}{*}{ Sig } \\
\hline & B & Std. Error & & & \\
\hline (Constant) & 7.06 & 1.38 & & 5.11 & .00 \\
\hline Emergence & .19 & .16 & .12 & 1.21 & .23 \\
\hline $\begin{array}{l}\text { Collective } \\
\text { Wisdom }\end{array}$ & .02 & .13 & .02 & .14 & .89 \\
\hline Obliquity & .55 & .12 & .46 & 4.61 & .00 \\
\hline Intrinsic & .32 & .13 & .25 & 2.47 & .02 \\
\hline$R=0.59$ & $R^{z}=0.35$ & $\mathrm{f}^{2}=0.54$ & & & \\
\hline$F_{(6.75)}=10.12$ & $p=0.00$ & & & & \\
\hline
\end{tabular}

\section{Discussion}

Our analyses put forth that the "discovery model" shows the strongest influence on product innovativeness, followed by the "science model" and the "quest model", respectively. Regarding the impact of management principles, our results show that the impact of obliquity and intrinsic motivation turned out to be especially strong, exerting significant impact both through management models and on an individual basis. Also, the emergence principle was found to be a significant predictor of product innovativeness.

The findings present mixed results regarding the alignment principle. Despite the non-significant individual impact on product innovativeness, alignment combined and interacting with other principles in the quest model was found to contribute to firm product innovativeness. This finding indicates that, rather than acting as an independent variable with direct impact on product innovativeness, goal alignment might portray an impact as an intervening variable. This is also in line with previous literature discussing that "context matters" for goal alignment to foster product innovativeness, specifically with regard to the varying impact of certain environmental factors on several forms of alignment (as put forth by Acur et al., 2012), and the possible impact of other variables such as visionary leadership and communication quality (Mascareno et al., 2020). Therefore, we recommend that future research should focus on the relationship of goal alignment with other organizational variables to clarify its impact on product innovativeness.
Our findings indicate that both intrinsic motivation and extrinsic motivation can be significant enablers of product innovativeness, making "motivation" the only management model pillar in our study that enabled product innovativeness both through alternative and traditional principles.

Intrinsic motivation thus bears a motivating role, especially for the high qualified employees (also known as, "golden collar workers") in technology firms. Recent literature also supports this by underlining the role of intrinsic motivating factors in fostering the stimuli to create something new, look for new opportunities, and continuously think on how to create new products or improve existing ones (Alvesson, 2000; Holland et al., 2012). In their study on micro- and small-sized software development companies in Turkey, Gumusoglu and Ilsev (2009) also found a strong influence from intrinsic motivation as a mediator variable on innovation and creativity.

Our findings also indicate a significant role from extrinsic motivation in enabling product innovativeness. Extrinsic motivation turned out to be influential in technology firms, just as with intrinsic motivation. In other words, intrinsic motivating factors are critical in initiating the new product development process, while people still expect visible rewards after they create new products that enhance or strengthen the competitive market position of their company. 


\section{Embracing Product Innovativeness in Technology Firms: The Impact of Management Model Principles}

\section{Pınar Büyükbalcı, Esin Ertemsir \& Zayneb Boukari}

The obliquity principle's strong impact on product innovativeness shows the importance of sometimes setting only loosely defined boundaries while pursuing company goals. In other words, in order to harness creativity, following an oblique principle such as, "our company will beat our rivals by being the first to market", "we want to position ourselves as a company always offering novel products" will likely pay off more than always clearly defining and imposing from the topdown specific objectives.

In terms of coordinating new product development processes, the principle of emergence turns out to be an enabling factor. Emergence is closely relevant to coordinating activities and the execution phase of new product development, rather than the idea generation process. Specifically, it refers to deciding which rules and procedures to follow in developing new products and making them function. As Mintzberg and McHugh (1985) described with the term "adhocracy", it is crucial for the sake of creativity to give up or minimize bureaucracy and instead design a new form of coordination system with an innovative approach. A flexible, ad-hoc structure in this view expects to enable possible cooperation among employees, which in turn may foster product innovativeness (Pullen et al., 2009; Naranjo-Valencia et al., 2017) by liberating the coordination of their activities.

Another important finding from our study is that none of the decision-making principles, not collective wisdom nor bureaucracy is found to be a significant enabler of product innovativeness. Despite previous research that posed collective wisdom as an enabler of product innovativeness (Malhotra et al., 2017), our current study finds that controversial, and underlines what appears to be a non-significant role for collective wisdom. This is in line with a recent study by Zahay et al. (2018) that challenged the value and impact of internally crowdsourced ideas during NPD.

Despite the non-significant impact of "bureaucracy" on product innovativeness, our findings show that the "science model", including bureaucracy as a principle, portrays a statistically significant explanation. On the other hand, the "planning model" exerted no significant impact on product innovativeness. This finding supports Damanpour's (1996), which underlined that future research should identify specific conditions that unveil possibly varying impacts of bureaucracy on innovation. Also, the changing role of bureaucracy in this study put an emphasis on Dougherty and Corse
(1995), who mentioned that "useful re-conceptions of bureaucracy's relationship with innovation ... may help resolve persistent problems both in theory and in the real world".

Not all management models were applicable to this study's sample. For example, the planning model with its prescriptive nature was not expected be preferred in a dynamic entrepreneurial context. Still, we did not place such a limitation on the research and did not exclude it from our analyses in order not to restrict possible interactions among variables. However, as expected, 3 of the four models - the science model, quest model, and discovery model -were found to be supportive when the combined impact of all principles were checked. It is reasonable to observe the impact of these rather "proactive" models when the fast changing and highly complex character of technology-oriented companies.

\section{Conclusion}

The main purpose of this study was to investigate the impact of management model principles on product innovativeness. By unveiling several possible impacts, we aimed to open a new venue to discuss how product innovativeness is enabled by using specific management principles. Thus, we aimed to help companies develop a better understanding of the role of management models in fostering product innovativeness. The study in this respect contributes to the field of business management through an empirical examination of strategic factors that affect product innovativeness.

Future research might explore other variables to extend the discussion. For instance, the type of product developed might affect which management principles should be used to foster product innovativeness. As found by Saranga et al. (2018), when the nature of product development is rather "adaptation" and incremental modifications of existing products, a more structured process to develop products will be appropriate. Such differences might highlight special cases where certain principles become more (or less) affective in supporting product innovativeness. Due the sample firms we chose, the current study largely includes "new-to-the-market" products. Further studies should pay attention to products and include alternative modes of product development to address the impact of management principles more thoroughly. 


\title{
Embracing Product Innovativeness in Technology Firms: The Impact of Management Model Principles
}

\author{
Pınar Büyükbalcı, Esin Ertemsir \& Zayneb Boukari
}

An unexpected finding of the study was the apparent insignificant impact of collective wisdom. In techoriented industries, the collaborative development processes in open-source software communities widely source from external parties. Online communities are also considered important sources of ideas for brand or line extensions, as well as product re-positioning (Ogawa \& Piller, 2006; Christensen et al., 2017). Thus, to better analyze the impact of collective wisdom, we suggest that future studies examine comparisons among "in-crowd" sourcing vs. sourcing from external "crowds".

The limitations of our study also suggest promising opportunities for future research. One such limitation is its single country and single firm type (entrepreneurial high-tech firms) focus. To enrich the discussion here, future studies could therefore benefit from expanding research across different sectors and countries. Such comparisons will let researchers discuss additional relationships in a more comprehensive manner.

The main weakness of this study is the small sample size. With a small sample size, caution must be applied. To generalize the findings, future research should replicate similar research with broader samples. Nevertheless, an obvious strength of the current research design and activities lay in our access to "managers". Their responses helpfully reflected the essence of the company's management model. Thus, the findings of our research serve the purpose of raising awareness about the topic, while we strongly encourage that further research be undertaken with broader samples and additional methodologies.

\section{References}

Acur, N., Kandemir, D., \& Boer, H. 2012. Strategic Alignment and New Product Development. The Journal of Product Innovation Management, 29: 304318. https://doi.org/10.1111/j.1540-5885.2011.00897.x

Alvesson, M. 2000. Social identity and the problem of loyalty in knowledge-intensive companies. Journal of Management Studies, 37(8): 1101-1123. https://doi.org/10.1111/1467-6486.00218

Basile, A., \& Foraci, R. 2015. Aligning management model and business model in the management innovation perspective: The role of managerial dynamic capabilities in the organizational change. Journal of Organizational Change Management, 28(1): 43-58.

https://doi.org/10.1108/JOCM-10-2013-0199

Birkinshaw, J., \& Ansari, S. 2015. Understanding Management Models: Going Beyond what and why, to how work gets done in organizations. In N.J. Foss, \& T. Saebi (Eds), Business Model Innovation: The Organizational Dimension, Oxford University Press, Oxford: 85-103.

https:// www.doi.org/10.1093/acprof:oso/9780198701 873.003.0005

Birkinshaw, J. 2012. Reinventing Management. San Francisco: Jossey-Bass.

Birkinshaw, J. 2010. The critical need to reinvent management. Business Strategy Review, Spring Issue: 4-11. https://doi.org/10.1111/j.1467-8616.2010.00636.x

Birkinshaw, J., \& Goddard, J. 2009. What is your management model? MIT Sloan Management Review: 81-90.

Bodrožić Z, \& Adler P.S. 2018. The Evolution of Management Models: A Neo-Schumpeterian Theory. Administrative Science Quarterly, 63(1): 85-129. https://doi.org/10.1177/0001839217704811

Casebourne, J. 2014. Why motivation matters in public sector innovation. London, United Kingdom: Nesta.

Christensen, K., Nørskov, S., Frederiksen, L., \& Scholderer, J. 2017. In search of new product ideas: Identifying ideas in online communities by machine learning and text mining. Creativity and Innovation Management, 26(1): 17-30.

https://doi.org/10.1111/caim.12202

Clegg, C., Unsworth, K., Epitropaki, O., \& Parker, G. 2002. Implicating trust in innovation process. Journal of Occupational and organizational psychology, 75(4): 409-422. https://doi.org/10.1348/096317902321119574

Cooper, R.G., \& Kleinschmidt, E.J. 2000. New product performance: What distinguishes star products. Australian Journal of Management, 25(1): 17-46. https://doi.org/10.1177/031289620002500104 


\section{Embracing Product Innovativeness in Technology Firms: The Impact of Management Model Principles}

\section{Pınar Büyükbalcl, Esin Ertemsir \& Zayneb Boukari}

Cohen, J. 1988. Statistical Power Analysis for the Behavioral Sciences (2nd ed.). Hillsdale: NJ: Lawrence Earlbaum Associates.

Conway, S., \& Steward, F. 2009. Managing and Shaping Innovation. Oxford University Press.

Daft, R.L. 1978. A dual-core model of organizational innovation. The Academy of Management Journal, 21(2): 193-210.

https://www.doi.org/10.2307/255754

D'Amato, V. 2015. Management innovation roadmap. Milano: EGEA.

Damanpour, F. 1996. Bureaucracy and innovation revisited: Effects of contingency factors, industrial sectors, and innovation characteristics. The Journal of High Technology Management Research, 7(2): 149-173.

https://doi.org/10.1016/S1047-8310(96)90002-4

Damanpour, F. 1991. Organizational innovation: A meta-analysis of effects of determinants and moderators. Academy of Management Journal, 34: 355-390.

https://doi.org/10.5465/256406

Dougherty, D., \& Corse, S. 1995. When it comes to product innovation, what is so bad about bureaucracy? The Journal of High Technology Management Research, 6 (1): 55-76.

https://doi.org/10.1016/1047-8310(95)90006-3

Ekvall, G. 1999. Encyclopedia of Creativity. Academic Press.

Ellonen, R., Blomqvist, K., \& Puumalainen, K. 2008. The role of trust in organizational innovativeness. European Journal of Innovation Management, 11(2): 160-181.

https://doi.org/10.1108/14601060810869848

Foss, N., \& Saebi, T. 2015. Business model innovation. Oxford: Oxford University Press.

Green, S.B. 1991. How many subjects does it take to do a regression analysis? Multivariate behavioral research, 26(3): 499-510.

https://doi.org/10.1207/s15327906mbr2603_7

Gupta, B. 2009. Understanding the preferences of creative and non-creative employees. Indian Journal of Industrial Relations, 45(2): 289-301.

https://www.jstor.org/stable/20788267

Gumusoglu, L., \& Ilsev, A. 2009, Transformational Leadership Creativity, and Organizational Innovation. Journal of Business Research, 62: 461-473.

https://doi.org/10.1016/j.jbusres.2007.07.032

Harold, L.A. 2000. Psychology and organizational innovation. In A.H. Van de Ven, L.A. Harold, \& M.S. Poole (Eds.), Research on the management of innovation. New York: Oxford University Press.
Herting, A.M, \& Schmidt, A.L. 2020. A Systematic Analysis of how Practitioners Articulate Business Models across Disruptive Industries. Technology Innovation Management Review, 10(10): 29-42. http:/ / doi.org/10.22215/timreview/1394

Holland, P.J., Hecker, R., \& Steen, J. 2012. Human resource strategies and organizational structures for managing gold-collar workers. Journal of European Industrial Training, 26(2/3/4): 72-80.

https://doi.org/10.1108/03090590210421941

Hult, G.T., Hurley, R.F., \& Knight, G.A. 2004. Innovativeness: Its antecedents and impact on business performance. Industrial Marketing Management, 33: 429-438.

http://dx.doi.org/10.1016/j.indmarman.2003.08.015

Kessler, E., \& Chakrabati, K. 1999. Speeding up the pace of new product development. Journal of Product Innovation Management, 16: 231-247.

https://doi.org/10.1111/1540-5885.1630231

Koberg, C.S., Uhlenbruck, N., \& Sarason, Y. 1996. Facilitators of organizational innovation: The role of life-cycle stage. Journal of Business Venturing, 11(2): 133-149.

https://doi.org/10.1016/0883-9026(95)00107-7

Lahiri A., Pahnke E.C., Howard M.D., Boeker W. 2019. Collaboration and informal hierarchy in innovation teams: Product introductions in entrepreneurial ventures. Strategic Entrepreneurship Journal, 13: 326358.

https://doi.org/10.1002/sej.1331

Lave, J., \& Wenger, E. 1991. Legitimate Peripheral Participation in Communities of Practice. Situated Learning: Legitimate Peripheral Participation. Cambridge: Cambridge University Press. https:// doi.org/10.1017/CBO9780511815355.006

Malhotra, A., Majchrzak, A., Kesebi, L., \& Looram, S. 2017. Developing innovative solutions through internal crowdsourcing. MIT Sloan Management Review, 58(4): 73-79.

Mascareño, J., Rietzschel, E., \& Wisse, B. 2020. Envisioning innovation: Does visionary leadership engender team innovative performance through goal alignment? Creativity and Innovation Management, 29: 33-48. https://doi.org/10.1111/caim.12341

McGraw, K.O. 1978. The detrimental effects of reward on performance: A literature review and a prediction model. In M.R. Leer, \& D. Greene (Ed.), The Hidden Costs of Reward: New Perspectives on the Psychology of Human Motivation, London: Psychology Press.

McKnight, D.H., \& Chervany, N.L. 2001. Trust and distrust definitions: One bite at a time. Trust in cyber societies. Springer Publishing. https://www.doi.org/10.1007/3-540-45547-7_3 


\section{Embracing Product Innovativeness in Technology Firms: The Impact of Management Model Principles}

\section{Pınar Büyükbalcı, Esin Ertemsir \& Zayneb Boukari}

Mintzberg, H., \& McHugh, A. 1985. Strategy formation in an adhocracy. Administrative Science Quarterly, 30(2): 160-197.

https://www.doi.org/10.2307/2393104

Mohnen, P., \& Hall, B.H. 2013. Innovation and Productivity: An Update. Eurasian Business Review, 3: 47-65.

https:/ /www.doi.org/10.14208/BF03353817

Naranjo-Valencia, J.C., Jimenez-Jimenez, D., \& SanzValle, R. 2017. Impact of organizational culture on new product success: An empirical study of Spanish firms. European Management Review, 14(4): 377-390. https://doi.org/10.1111/emre.12116

Ogawa, S., \& Piller, F.T. 2006. Reducing the risks of new product development. MIT Sloan Management Review, 47: 65-71.

Olson, E.M., Walker, O.C., Jr., \& Ruekert, R.W. 1995. Organizing for effective new product development: The moderating role of product innovativeness. Journal of Marketing, 59: 48-62. https://www.doi.org/10.2307/1252014

Osterwalder, A. 2004. The Business Model Ontology - a proposition in a design science approach. Dissertation, University of Lausanne, Switzerland: 173.

Prahalad, C.K., \& Bettis, R.A. 1986. The dominant logic: A new linkage between diversity and performance. Strategic Management Journal, 7(6): 485-501. https://doi.org/10.1002/smj.4250070602

Pullen, A., de Weerd-Nederhof, P., Groen, A., Song, M., \& Fisscher, O. 2009. Successful patterns of internal SME characteristics leading to high overall innovation performance. Creativity and Innovation Management, 18(3): 209-223.

https://doi.org/10.1111/j.1467-8691.2009.00530.x

Saranga, H., George, R., Beine, J., \& Arnold, U. 2018. Resource configurations, product development capability, and competitive advantage: An empirical analysis of their evolution. Journal of Business Research, 85: 32-50.

https://www.doi.org/10.1016/j.jbusres.2017.11.045

Tabachnick, B.G., \& Fidell, L.S. 1989. Using multivariate statistics. Cambridge, MA: Harper \& Row.

Wang, C.L., \& Ahmed, P.K. 2004. The development and validation of the organizational innovativeness construct using confirmatory factor analysis. European Journal of Innovation Management, 7(4): 303-313.

https://doi.org/10.1108/14601060410565056

Wong, V. 2002. Antecedents of international new product rollout timeliness. International Marketing Review, 19(2): 120-132.

http://dx.doi.org/10.1108/02651330210424999

Yusof, N. 2010. Innovation and innovativeness: Difference and antecedent relationship. The IUP Journal of Architecture, 2(1): 66-78.

https://ssrn.com/abstract $=1564646$
Zahay, D., Hajli, N., \& Sihi, D. 2018. Managerial perspectives on crowdsourcing in the new product development process. Industrial Marketing Management, 71: 41-53.

https://doi.org/10.1016/j.indmarman.2017.11.002

Zott, C., \& Amit, R. 2010. Business Model Design: An Activity System Perspective. Long Range Planning, 43 (2-3): 216-226.

https://doi.org/10.1016/j.lrp.2009.07.004

\section{About the Authors}

Pınar Büyükbalcı is an Associate Professor at Yildiz Technical University - Department of Business Administration, Istanbul. Her research spans entrepreneurship (international entrepreneurship, entrepreneurship ecosystems, subsidiary level entrepreneurship), innovation strategies and multinational network structure. She is also the coauthor of five books, including case studies on management and entrepreneurship.

Esin Ertemsir is an Assistant Professor at Yildiz Technical University - Department of Business Administration, Istanbul. She previously held a position as a visiting doctoral student at the British University in Dubai, United Arab Emirates. Her research interests include innovation, creativity, and human resource management, as well as interdisciplinary studies such as innovative approaches to management education.

Zayneb Boukari is a Ph.D. student at Istanbul Commerce University. She obtained an undergraduate degree in Business Administration and a master's degree in Entrepreneurship and Innovation at Yıldiz Technical University. Her current research interests include entrepreneurship, innovation, business models, and exporting. She is supported by a Tübitak 2215 program scholarship.

Citation: Büyükbalcı, P., Ertemsir, E., \& Boukari, Z. 2020. Embracing Product Innovativeness in Technology Firms: The Impact of Management Model Principles. Technology Innovation Management Review, 10(12): 31-45. http://doi.org/10.22215/timreview/1408

Keywords: Product innovativeness, Innovation, Management Model, Technology firms 